Issued by Sandia National Laboratories, operated for the United States Department of Energy by Sandia Corporation.

NOTICE: This report was prepared as an account of work sponsored by an agency of the United States Government. Neither the United States Government, nor any agency thereof, nor any of their employees, nor any of their contractors, subcontractors, or their employees, make any warranty, express or implied, or assume any legal liability or responsibility for the accuracy, completeness, or usefulness of any information, apparatus, product, or process disclosed, or represent that its use would not infringe privately owned rights. Reference herein to any specific commercial product, process, or service by trade name, trademark, manufacturer, or otherwise, does not necessarily constitute or imply its endorsement, recommendation, or favoring by the United States Government, any agency thereof, or any of their contractors or subcontractors. The views and opinions expressed herein do not necessarily state or reflect those of the United States Government, any agency thereof, or any of their contractors.

Printed in the United States of America. This report has been reproduced directly from the best available copy.

Available to DOE and DOE contractors from

U.S. Department of Energy

Office of Scientific and Technical Information

P.O. Box 62

Oak Ridge, TN 37831

Telephone: (865)576-8401

Facsimile: (865)576-5728

E-Mail: reports@adonis.osti.gov

Online ordering: http://www.doe.gov/bridge

Available to the public from

U.S. Department of Commerce

National Technical Information Service

5285 Port Royal Rd

Springfield, VA 22161

Telephone: (800)553-6847

Facsimile: (703)605-6900

E-Mail: orders@ntis.fedworld.gov

Online order: http://www.ntis.gov/ordering.htm

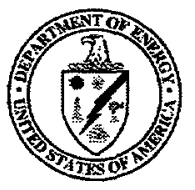




\section{DISCLAIMER}

Portions of this document may be illegible in electronic image products. Images are produced from the best available original document. 
SAND2000-2212

Unlimited Release

Printed September 2000

\title{
The Rise of Federally Funded Research and Development Centers
}

\author{
Bruce C. Dale \\ Executive Communications Department \\ Sandia National Laboratories \\ P.O. Box 5800 \\ Albuquerque, NM 87185-0131 \\ Timothy D. Moy \\ Department of History \\ University of New Mexico \\ Albuquerque, NM 87131-1181 \\ RECENVE \\ ОСТ 042000 \\ OS 7
}

\begin{abstract}
Federally funded research and development centers (FFRDCs) are a unique class of research and development (R\&D) facilities that share aspects of private and public ownership. Some FFRDCs have been praised as national treasures, but FFRDCs have also been the focus of much criticism through the years. This paper traces the history of FFRDCs through four periods: (1) the World War II era, which saw the birth of federal R\&D centers that would eventually become FFRDCs; (2) the early Cold War period, which exhibited a proliferation of FFRDCs despite their unclear legislative status and growing tension with an increasingly capable and assertive defense industry; (3) the re-evaluation and retrenchment of FFRDCs in the 1960s and early 1970s, which resulted in a dramatic decline in the number of FFRDCs; and (4) the definition and codification of the FFRDC entity in the late 1970s and 1980s, when Congress and the executive branch worked together to formalize regulations to control FFRDCs. The paper concludes with observations on the status of FFRDCs at the end of the twentieth century.
\end{abstract}


Page intentionally blank 


\title{
The Rise of Federally Funded Research and Development Centers
}

\author{
Bruce C. Dale and Timothy D. Moy
}

\section{Introduction}

Federally funded research and development centers (FFRDCs) are a unique class of research and development (R\&D) facilities that share aspects of private and public ownership. One contemporary observer of the early Atomic Energy Commission laboratories described the arrangement as

an amalgam of capitalism and socialism; it has divided the traditional attributes of property and dissolved differences of form in the organization of public and private businesses. The result is a politico-economic innovation which defies simple characterization. ${ }^{1}$

Some FFRDCs have been praised as national treasures or jewels in the crown of federal R\&D. But FFRDCs have also been the focus of much criticism through the years, particularly within the Department of Defense, and more recently in the Department of Energy. FFRDCs' unique blend of private and public ownership, management, and operation has led to occasional friction with both private industry and the federal government.

This paper traces the history of FFRDCs through four periods: (1) the World War II era, which saw the birth of federal R\&D centers that would eventually become FFRDCs; (2) the early Cold War period, which exhibited a proliferation of FFRDCs despite their unclear legislative status and growing tension with an increasingly capable and assertive defense industry; (3) the re-evaluation and retrenchment of FFRDCs in the 1960s and early 1970s, which resulted in a dramatic decline in the number of FFRDCs (from 74 in 1969 to 39 in 1976); ${ }^{2}$ and (4) the definition and codification of the FFRDC entity in the late 1970s and 1980s, when Congress and the executive branch worked together to formalize regulations to control FFRDCs. The paper concludes with observations on the status of FFRDCs at the end of the twentieth century.

Bruce C. Dale is a senior administrator at Sandia National Laboratories, Albuquerque, New Mexico. Timothy D. Moy, Ph.D., is an assistant professor of history at the University of New Mexico. 


\section{World War II-Origins of FFRDCs}

Apart from agriculture, the federal government funded very little research in the sciences prior to World War II. Since the beginning of the century, many leading scientists and their professional organizations had lobbied Washington for more direct support of science. ${ }^{3}$ Some federal money flowed to the sciences during the emergency of World War I; however, virtually all of this wartime $R \& D$ was performed in intramural government and military laboratories.

World War II changed everything. Franklin Roosevelt's administration, enamored of academic research since the days of the early New Deal, created the National Defense Research Council (NDRC) in 1940 and expanded it into the Office of Scientific Research and Development (OSRD) in mid-1941. Over the course of the war, OSRD oversaw approximately $\$ 500$ million in research contracts with universities and private industry, and exercised partial control over the $\$ 2$ billion spent on the Manhattan Engineer District (MED). ${ }^{4}$ In return, the government received radar, the proximity fuse, mass-produced penicillin, rockets, and the atomic bomb, arnong other innovations.

OSRD created several research centers, most of them affiliated with universities. They included several that would eventually become FFRDCs for the Department of Defense: the Radiation Laboratory at the Massachusetts Institute of Technology (later reorganized as Lincoln Laboratories); the Applied Physics Laboratories, operated by Johns Hopkins University; the Center for Naval Analyses in Arlington, Virginia, operated by the University of Rochester; and the Naval Ordnance Research Laboratory at Pennsylvania State University. In 1943, the Army Air Forces began supporting a rocket research division at the California Institute of Technology that was the precursor to the Jet Propulsion Laboratory, which later became an FFRDC for the National Aeronautics and Space Administration. ${ }^{5}$

Similarly, the Manhattan Engineer District created several centers devoted to research and development in nuclear energy. Many of them would eventually become laboratories for the Atomic Energy Commission and then the Department of Energy: Los Alamos Laboratory, managed by the University of California; Ames Laboratory, operated by Iowa State University; the Metallurgical Laboratory (later Argonne Laboratory) at the University of Chicago. Research sites at Hanford, Washington, and Clinton, Tennessee, operated by DuPont Chemical Company and the University of Chicago respectively, were 
the forerunners of Pacific Northwest and Oak Ridge national laboratories. The AEC's Lawrence Berkeley Radiation Laboratory had roots that preceded the war, having been established in 1936 by Ernest O. Lawrence as the University of California's Radiation Laboratory.

\section{The Post-War Transition}

After the war, it was clear that R\&D in science and engineering was now a fundamental element of national security. After nearly two years of debate in Washington over civilian versus military control of nuclear research, the remnants of the Manhattan Engineer District were folded into the new, civilian, Atomic Energy Commission (AEC) in 1947. The philosophy of the AEC was to continue the successful contractual formula that the MED had followed during the war and to avoid dramatic changes in laboratory governance. The University of Chicago, however, viewed peacetime management of nuclear production facilities as incompatible with its educational mission, and it requested to be relieved of its responsibilities in that arena. The AEC arranged for the Monsanto Chemical Company to take over management of the Clinton Laboratories at Oak Ridge from the University of Chicago even before the war ended. ${ }^{6}$

The University of California had few scruples about continuing to operate Los Alamos for nuclear weapons development, especially after weapons production engineering was spun-off to the Sandia Laboratory in Albuquerque. Both the University of Chicago and the University of California agreed to continue operating the scientific laboratories at Argonne and Berkeley, respectively, which would no longer perform weapons research.

The Office of Scientific Research and Development was dissolved shortly after the war, and many of its contracts were terminated. One notable exception was the Navy's AntiSubmarine Warfare Operations Research Group that had been active with the MIT Radiation Laboratory during the war. The group's work had impressed Chief of Naval Operations Admiral Ernest King with its contribution to anti-submarine warfare, and he did not want the organization dissolved. The Navy persuaded MIT to manage and operate the lab under a new name, the Operations Evaluation Group. ${ }^{7}$

It is important to note that both the AEC and the Navy could have absorbed these laboratories into the federal government as civil service or military laboratories, but chose 
not to. The AEC clearly had statutory authority to create government laboratories for its missions. ${ }^{8}$ A principal reason for not doing so was that most of the scientific staff clearly did not want to be in the military or the civil service. As a general rule, they preferred university and industrial settings, where they could enjoy greater freedom and better salaries. Thus, FFRDCs were a hybrid arrangement whereby the federal government could harness some of the nation's best scientific resources for its own purposes.

\section{Early Cold-War Growth in FFRDCs}

Several new FFRDCs were created during the first two decades of the Cold War. In 1951 , there were 23 such centers $;^{9}$ by 1969 the number had peaked at $74 .{ }^{10}$ Many were operated by universities or university consortia. Some were managed by private non-profit corporations. For the most part, industrial contractors did not fare well as operators of FFRDCs, except within the Atomic Energy Commission.

\section{Academe}

Many universities around the country were eager to emulate the University of California and the University of Chicago in operating large research centers for the federal government. One of the last acts of General Leslie Groves as director of the MED was to create a new research laboratory in the Northeast, a region to which many of the scientists who had worked on the atomic bomb were returning. Columbia University was a leading candidate for operating the new Brookhaven Laboratory in New York, but several other universities also were qualified and lobbied for the job. Groves suggested a consortium, and in July 1946, nine regional universities formed Associated Universities, Inc. (AUI), which was awarded the contract.*

AUI's success encouraged other universities to establish regional consortia to bid for management contracts for research laboratories of the AEC and the National Science Foundation (NSF). In practice, consortia tended to win awards for basic science facilities, such as the NSF radio astronomy observatories and the Fermi National Accelerator Laboratory, while mission-oriented research and development laboratories were awarded to single universities. 


\section{Department of Defense}

For the Department of Defense, the compelling reasons for establishing FFRDCs were its needs for (1) policy advice for operational and strategic planning and (2) relatively unbiased technical counsel and integration expertise for major system developments. ${ }^{11}$ In response to the first need, DoD created a series of study and analysis centers ("think tanks"), beginning with RAND in 1946. In response to the second need, it later established several system engineering and technical direction centers.

RAND became the prototype of the think tanks. Toward the end of 1945, General Henry "Hap" Arnold, commander of the Army Air Forces, proposed a contract with Douglas Aircraft Company to create a study and analysis center to conduct "scientific study and research on the broad subject of air warfare" with the explicit purpose of advising the Air Force on future trends in air power, particularly with respect to nuclear weapons. Douglas agreed to the proposal, and Air Force Project RAND (for "R and D") opened its doors at Douglas Aircraft in Santa Monica, California, the following year. ${ }^{12}$

However, it became apparent during the first two years of operation that the arrangement was not satisfactory. Douglas Aircraft began to regard RAND as a business liability; it believed that the Air Force, in its eagerness to appear fair, had favored other contractors in competitive procurements for aircraft production. ${ }^{13}$ The Air Force (a separate service after September 1947) felt that Douglas was not giving RAND the attention it should and was making an excessive profit from it. By mutual agreement, Douglas Aircraft was released from its contract in 1948, and the RAND Corporation was created as an independent, private entity specifically to operate the analysis center. ${ }^{14}$ The problems of conflict of interest, real or perceived, would be avoided by using an independent non-profit corporation rather than an industrial contractor.

At first, the sole patron of the new RAND Corporation remained the Air Force. But eventually, RAND would manage three FFRDCs on a permanent basis, some for other elements of the Defense Department: Project Air Force, the originally conceived study and analysis center; the National Defense Research Institute for the Office of the Secretary of Defense; and the Arroyo Center for the Army. ${ }^{15}$ In addition, in 1957 it spun off the System

\footnotetext{
* The member universities were Columbia, Cornell, Harvard, Johns Hopkins, MIT, Pennsylvania, Princeton,
} 
Development Corporation, an FFRDC that had developed software for the nation's air defense system, ${ }^{16}$ and in 1958, Analytic Services, Incorporated (ANSER), an analysis group located in Virginia that performed cost studies and evaluations of weapon system proposals for the Defense Department's Directorate of Development Planning. ${ }^{17}$ RAND's success inspired other agencies to create similar study and analysis centers, including the Army Operations Research Organization (1948), the Institute for Defense Analyses for the Office of the Secretary of Defense (1956), and the Center for Naval Analyses (1962).

The first systems engineering FFRDC for the Department of Defense (DoD) was the Space Technologies Laboratory (STL). The Air Force realized that the prospect of designing fleets of intercontinental ballistic missiles (ICBMs) was a challenge that required technical expertise unavailable in the military. In 1954, it contracted with Ramo-Wooldridge, a commercial engineering firm, to assist it with technical integration of the work performed by industrial contractors designing and producing ICBMs. To avoid conflict of interest, the company agreed not to bid on hardware production contracts for the ICBM program. RamoWooldridge also insulated STL from its commercial operations by establishing a separate non-profit subsidiary.

Lincoln Laboratories, which had been reconstituted in 1951 as an FFRDC from the remnants of the wartime Radiation Laboratory at MIT, was engaged in evaluating the technical feasibility of SAGE, a complex air defense system. MIT was reluctant to support the design of the system at the engineering level, however. The Air Force created a new FFRDC, MITRE Corporation, for that purpose in $1956 .^{18}$ MITRE played a major role in the technical evaluation and integration of the air defense system. Later, it played a similar role in the development of the nation's air traffic control system for the Federal Aviation Administration.

\section{Atomic Energy Commission}

In general, the Atomic Energy Commission (AEC) relied on universities or university consortia to operate its FFRDCs. However, there were important exceptions to this practice. The American Telephone and Telegraph Company was persuaded to accept the contract for the Sandia Laboratory, which was responsible for systems engineering of 
nuclear weapons and the technical direction of a manufacturing complex for producing a stockpile. The AEC commissioners regarded the technical prowess of Bell Laboratories and the manufacturing expertise of Western Electric as important dual strengths unique to AT\&T. ${ }^{19}$ Monsanto Chemical Company operated Oak Ridge, and was succeeded there by Union Carbide and Carbon Company. During this early period, AEC contractors did not face the conflict-of-interest charges that were already surfacing at DoD, since the Atomic Energy Act prohibited a commercial nuclear weapons industry.

\section{Congressional and Executive Concern over FFRDCs, 1958-1963}

By the latter 1950s, the proliferation of FFRDCs started attracting critical attention from Capitol Hill and the White House. In 1958, a staff paper for the House Committee on Government Operations suggested that the unique nature of federal research and development contracts called for a possible overhaul of the R\&D contracting process:

While the evidence is not entirely clear, it does seem to be true that contracting methods and specifications appropriate to the administration of traditional functions of the federal government have been carried over by brute force and sheer awkwardness into the area of scientific research contracting, in which they protect adequately the interests neither of the federal government nor the contractor. ${ }^{20}$

Not only were FFRDCs proliferating at dizzying rate, but some of the arrangements posed questions of propriety and raised the specter that publicly funded government labs might be competing with private industry.

The Eisenhower administration took an interest in the issue precisely because it regarded much of the work of FFRDCs as more appropriate for industry. In 1960, Maurice Stans, director of the Bureau of the Budget, issued a bulletin to executive agencies cautioning them on FFRDCs:

Even the operation of a Government-owned facility by a private organization through contractual arrangement does not automatically assure that the Government is not competing with private enterprise. ${ }^{21}$

For example, the Space Technologies Laboratory (STL) raised eyebrows when its manager, Ramo-Wooldridge, merged with Thompson Products to create TRW, Inc., in 1958. The new corporation indicated its intent simultaneously to compete for defense production contracts and to operate STL for the government. Competing defense contractors objected to the evident conflict of interest. Moreover, they perceived the work of STL to be within 
the capability of the wider aerospace industry; indeed, by 1960, the technical capabilities of industry rivaled those of STL.

The staff of the House Committee on Government Operations recommended that STL be converted to management by an independent non-profit organization on the RAND model. The General Accounting Office (GAO), on the other hand, argued that the Air Force should develop an intramural technical staff to do the work of the laboratory. In particular, GAO asserted that technical coordination of the ICBM program was an inherently governmental function that could not be delegated or contracted to a private entity. The House committee rejected the GAO argument, and in 1960, the private, non-profit Aerospace Corporation took over the duties of STL from TRW. ${ }^{22}$

The significance of this decision was far-reaching, for it was the first Congressional validation of the role of FFRDCs. If the committee had adopted GAO's position, the legitimacy of FFRDCs would have been jeopardized, and many FFRDCs could have been forced to become intramural civil service or military activities.

Eventually, some industry groups also criticized the Atomic Energy Commission for permitting its FFRDCs to compete with private industry. The U.S. Chamber of Commerce and the National Association of Manufacturers complained to the Joint Committee on Atomic Energy (JCAE) in 1960, but the committee, dominated by senators with AEC FFRDCs in their states (Senator Clinton Anderson of New Mexico was JCAE chairman), summarily dismissed their objections. ${ }^{23}$

Industry's objections were not without basis, however. Glenn Seaborg, the chairman of the Atomic Energy Commission, painted an expansive picture of potential non-atomicenergy programs for AEC FFRDCs, suggesting that they

could well advance the national interest by doing work on: long-range transmission of electricity; better control over environmental pollution; long-range prediction and control of weather; ... exploitation of ocean minerals; biophysics and biochemistry; and national resources. ${ }^{24}$

In 1961, Oak Ridge National Laboratory obtained permission from the AEC to perform research for the Department of the Interior on the desalination of sea water. The National Association of Manufacturers protested to the commission that the project exceeded the charter of the AEC and that industry should be given an opportunity to bid on this work. The commissioners dismissed the complaint and made clear their intention to permit the 
AEC FFRDCs to supplement their portfolios with programs for other federal agencies as the needs of the atomic energy program diminished. ${ }^{25}$ The JCAE upheld the AEC's decision.

In contrast to the position of the JCAE, the Congressional committees with jurisdiction over the Defénse Department tried to restrain, rather than expand, FFRDC portfolios. Complaints against FFRDCs came not only from defense contractors, but also from government employees. With arguments similar to those used in the General Accounting Office report to the Government Operations Committee, the American Federation of Government Employees submitted a statement to the House Armed Services Committee expressing concern over the adverse effects of contracting federal government work to private entities. In a similar vein, the House Appropriations Committee found that often "the use of contracts with not-for-profit organizations is merely a subterfuge to avoid the restrictions of civil service salary scales. ${ }^{26}$ As a further reflection of concern on Capitol Hill, in 1964 Congress placed a spending cap on the funds that the Department of Defense could obligate to FFRDCs.

At the same time, other voices within Washington endorsed the status of FFRDCs. An influential 1962 review of government contracting policy by President Kennedy's budget director, David Bell, recommended that the civil service salary structure be changed so that the government could attract outstanding technical people into government service; but it also recommended that FFRDCs perform work on complex technical programs. ${ }^{27}$ In addition, a staff report for the House Committee on Science and Astronautics in 1963 found that the Aerospace Corporation and similar research and development centers performed useful functions that justified their special status as FFRDCs. ${ }^{28}$

\section{Retrenchment and Downsizing, 1964-1976}

The 1964 spending cap created an institutional crisis for Defense FFRDCs. Since it was now bureaucratically impossible for them to grow by increasing their work for the Department of Defense, they adopted a strategy of diversifying their client base. In 1964, for example, the MITRE Corporation board of directors amended its incorporation papers to permit the FFRDC to accept work from non-federal customers. DoD did not discourage this action. $^{29}$ 
RAND boldly entered the domestic arena after 1967 under the direction of its new president, Henry Rowen. At the invitation of Mayor John Lindsay, RAND established a research center in New York City to study urban problems. Though it was often a pawn in the game of New York politics, by the end of the decade RAND had studied urban transportation, water supply, mental health, and local government data needs for the city of New York. ${ }^{30}$

Still, by 1968 , the funding situation was so desperate that Defense Secretary Clark Clifford appointed a committee to explore more ways of engaging DoD FFRDCs in social programs. Defense officials later claimed that President Johnson had directed that all cabinet departments contribute to solving domestic problems, thus providing DoD FFRDC managers authorization from the highest levels to diversify into new areas of study and analysis, even those not related to defense. ${ }^{31}$ This policy continued into the Nixon administration. Shortly after taking office, Nixon's Defense Secretary, Melvin Laird, sent a letter to the heads of other government agencies offering the services of the Defense contract research centers for domestic programs. ${ }^{32}$

In addition to the funding problems, FFRDCs were beginning to experience problems with customer satisfaction. The armed services were becoming increasingly dissatisfied with several aspects of FFRDCs' special status and performance. The services complained that many FFRDCs were too academic and not responsive to the Pentagon's needs. ${ }^{33}$ RAND's relationship with the Air Force began to deteriorate after 1964 with the appointment of a new Chief of Staff who felt that RAND was overstepping its bounds. In addition, campus protest over the expanding war in Vietnam quickly evolved into a criticism of university involvement in military $R \& D$, making the services wary of university management of FFRDCs. On August 24, 1970, the Army Mathematics Center at the University of Wisconsin, a small FFRDC, was fire-bombed, killing one researcher and injuring several others. The next year, Daniel Ellsberg, a former RAND staffer, leaked the Pentagon Papers, a classified and embarrassing study on U.S.-Vietnam relations. Incidents such as these, along with the general rise of a strong anti-military sentiment on campuses, caused the services to question the value of FFRDCs.

The tension over Vietnam shaped attitudes about federal R\&D spending in Congress as well. In 1969, Senator Mike Mansfield of Montana, determined to reduce Pentagon influ- 
ence in academe, successfully sponsored an amendment to the defense authorization bill that prohibited the DoD from funding any research that did not have a specific military purpose. Although the Mansfield Amendment was dropped the following year, it became a guiding principle of Congressional intent at the Pentagon, and a considerable amount of basic research money moved from the DoD to the National Science Foundation into the mid-1970s. By 1975, DoD funding for basic research to universities fell to 45 percent of what it had been in $1967 .{ }^{34}$

Moreover, in 1971, the House Appropriations Committee, clearly irritated at FFRDCs in general and at RAND in particular, stated that "the Committee feels strongly that the time has come for the military services to begin phasing out the 'think tank' operations which have been supported for more than two decades. ${ }^{35}$ In general, the services did not balk at this directive. By 1976, DoD sponsored only eight FFRDCs, down from a high of 39 in the early 1960s. ${ }^{36}$ Some FFRDCs had been terminated at the request of universities, some had been forced to enter the private sector and compete with the defense industry, and others were simply dissolved.

FFRDCs in the Atomic Energy Commission faced budget problems as well, but they emerged from this period with no major losses. Although the nuclear weapons budget dropped 29 percent in 1965, the AEC and its laboratories aggressively sought out supplementary, non-nuclear-weapons work. ${ }^{37}$ In addition, a politically popular and lucrative energy supply mission emerged for the labs under the Energy Research and Development Administration (ERDA) in the mid-1970s, which substantially recovered the laboratories' losses in nuclear weapons programs.

\section{Codification, 1976-1990}

Through the middle 1970s, the status of FFRDCs, especially within the Department of Defense, remained precarious. While a series of studies by a DoD task force, completed in 1976, heartily endorsed the use of FFRDCs by the Pentagon, ${ }^{38}$ Congress and the DoD itself continued to cut funding for the centers; by 1978, the DoD was operating only six FFRDCs.

FFRDCs were placed on much firmer bureaucratic ground in the Competition in Contracting Act (CICA) of 1983. The new law defined FFRDCs and outlined procedures for establishing them without competitive bidding. At the same time, CICA made it much 
more difficult for FFRDCs to perform work for agencies other than their primary sponsor, thus making it harder to "diversify" in times of budget cuts. ${ }^{39}$

One year later, the Office of Federal Procurement Policy (OFPP), a unit of the Office of Management and Budget (OMB), issued a policy statement on FFRDCs that remains in effect today. The statement gave guidance for the establishment, use, periodic review, and termination of FFRDCs. It required that before creating a new FFRDC, a sponsoring agency must ensure that (1) existing sources cannot meet the special research and development needs of the agency, (2) public notices are published indicating the agency's intention to sponsor an FFRDC, (3) the costs of FFRDC services are reasonable, and (4) the FFRDC's stated mission clearly indicates the kind of work it will perform. It also prohibited FFRDCs from competing with private industry in response to federal agency requests for proposals. The statement served both to constrain and to legitimatize FFRDCs. ${ }^{40}$ The Federal Acquisition Regulations were updated in 1990 to conform to the OMB guidelines.

\section{Observations}

At the turn of the century, the federal government funds thirty-seven FFRDCs. Ten belong to the Department of Defense (including one for the National Security Agency); seventeen are under the Department of Energy; five are funded through the National Science Foundation; and one each reside within the Department of Health and Human Services, the National Aeronautics and Space Administration, the Nuclear Regulatory Commission, the Department of Transportation, and the Department of Treasury. ${ }^{\dagger}$ It seems very unlikely that the number of FFRDCs will grow, inasmuch as it is increasingly difficult to meet the OMB criteria when the U.S. industrial base is so diverse and robust, and any such effort would encounter political opposition. On the other hand, established FFRDCs serving ongoing mission requirements for their agencies will probably endure. The FFRDCs of the Department of Energy, however, are likely to be subject to challenges to their governance and customary autonomy for some time.

\footnotetext{
$\dagger$ A master list of FFRDCs maintained by the National Science Foundation may be viewed via the Internet at http://www.nsf.gov/sbe/srs/fedfunds/pubs/ffrdc/ffrdc.htm.
} 


\section{Department of Defense FFRDCs}

In the late 1990s, the FFRDCs of the Department of Defense faced many of the same problems and criticisms they have always confronted. In 1995, DoD took actions to respond to congressional concerns that FFRDCs had grown too large, were working in areas beyond the core interests of $\mathrm{DoD}$, and were using their special status to gain an unfair competitive advantage over commercial firms. In testimony before the House National Security Committee in March 1996, Undersecretary of Defense for Acquisition and Technology Paul G. Kaminski reported that the department had instituted new management initiatives aimed at keeping FFRDCs focused on core mission work and improving the department's management and oversight. At the same time, he felt compelled to defend the work of the FFRDCs by citing several examples of crucial contributions they had made to defense missions. Kaminski enunciated four principles that characterize the role of FFRDCs in the DoD and distinguish them from other performers. FFRDCs:

- maintain long-term strategic relationships with their sponsoring DoD organizations;

- perform research, development, and analytic tasks integral to the mission and operations of sponsoring agencies with the DoD;

- maintain core competencies in areas important to the DoD sponsors and employ these competencies to perform high-quality, objective work that cannot be carried out as effectively by other organizations; and

- operate in the public interest, free from real or perceived conflicts of interest. ${ }^{41}$

The $104^{\text {th }}$ through $106^{\text {th }}$ Congresses were willing to tolerate the level of FFRDC funding in the Defense research, development, test, and evaluation (RDT\&E) budget-less than five percent-but seemed determined to hold the line on mission expansion and institutional growth. So long as DoD demonstrates control and restraint in managing its FFRDCs, it probably will not face serious challenges to their continued operation and existence.

\section{Department of Energy FFRDCs}

Department of Energy FFRDCs, on the other hand, face greater uncertainty at the end of the century than those of the Department of Defense. Whereas Congress is reasonably satisfied with the Defense Department's management of its FFRDCs, revelations of serious problems, wasteful practices, and blunders at FFRDC facilities and in DOE programs 
performed by FFRDCs have convinced many in Congress that DOE's management and oversight of its FFRDCs is unacceptable.

The first of a string of damaging revelations occurred in the late 1980s when it became clear that the Atomic Energy Commission and its FFRDCs responsible for the nation's nuclear weapons program had for decades operated with negligent disregard for environmental protection and occupational health and safety. During the 1990s, the Government Accounting Office issued a series of reports critical of DOE and its FFRDCs in such areas as environmental safety and health, financial management, contracting and procurement, technology transfer, travel costs, control of foreign visitors, security, and program management. The academic research community and some industry groups objected to perceived encroachment by the large national laboratories in areas of fundamental research or federal technology development programs. And in 1999, allegations of poor security at Los Alamos National Laboratory and other FFRDCs in the nuclear weapons program, ${ }^{42}$ resulting in the probable compromise of critical nuclear weapon design information to China, were extraordinarily damaging to Congressional confidence in DOE FFRDCs.

As a consequence of these developments, several legislative proposals were introduced in the late 1990s to change the organization and management of DOE FFRDCs. The most extreme proposals would have abolished the Department of Energy and transferred, privatized, or terminated its FFRDCs. Other legislation proposed reorganizing the nuclear weapons FFRDCs under a new administrative agency, transferring them to the Department of Defense, or imposing specific management reforms or levels of oversight. With the National Defense Authorization Act for Fiscal Year 2000, Congress acted on the recommendation of the President's Foreign Intelligence Advisory Board and placed the FFRDCs of the nuclear weapons program in a new National Nuclear Security Administration, a semiautonomous agency of the Department of Energy. This legislation did not alter the governance of those FFRDCs, however.

\section{Conclusion}

FFRDCs were created by federal government agencies to meet their needs for access to technical and scientific talent that was hard to attract into federal or military service. The proliferation of FFRDCs during the first half of the Cold War led to policy debates about their role, the extent to which they competed with private industry, and whether they 
usurped governmental functions. Several studies endorsed a role for FFRDCs while recommending that they be controlled and limited to specific defined missions. The codification of a definition of FFRDCs and rules of governance in 1983 moderated the controversy. However, to this day the issues are not completely resolved to the satisfaction of industry, universities, Congress, and policy makers. 


\section{REFIERENCES}

${ }^{1}$ Richard A. Tybout, Government Contracting in Atomic Energy (Ann Arbor: The University of Michigan Press, 1956), p. 2.

${ }^{2}$ Office of Technology Assessment, A History of the Department of Defense Federally Funded Research and Development Centers (Springfield, Va.: National Technical Information Service, 1995), p. 33.

${ }^{3}$ A. Hunter Dupree, Science in the Federal Government: A History of Policies and Activities to 1940 (Cambridge, Mass.: Harvard University Press, 1957); and Daniel J. Kevles, The Physicists: The History of a Scientific Community in Modern America (Cambridge, Mass.: Harvard University Press, 1971, 1995).

${ }^{4}$ James Phinney Baxter III, Scientists against Time (Boston: Little, Brown, 1946), pp. 456-457.

${ }^{5}$ Douglas L. Sanders, “Capturing Private Research and Development for Public Ends: The Government's Use of FFRDCs," National Contract Management Journal 26:1 (1995): Dialog, B-NCMJ-12-5, p. 3.

${ }^{6}$ Richard G. Hewlett and Oscar E. Anderson, Jr., The New World, 1939/1946: Volume I of A History of the United States Atomic Energy Commission (University Park, Penn.: Pennsylvania State University Press, 1962), p. 627.

${ }^{7}$ Office of Technology Assessment, p. 14.

${ }^{8}$ Sanders, p. 3.

'Harold Orlans, The Nonprofit Research Institute: Its Origin, Operation, Problems, and Prospects. (New York: McGraw-Hill, 1972), p. ix.

${ }^{10}$ Office of Technology Assessment, p. 33.

${ }^{11}$ Office of Technology Assessment, p. 12.

${ }^{12}$ Fred Kaplan, The Wizards of Armageddon (New York: Simon and Schuster, 1983), pp. 56-59.

${ }^{13}$ Kaplan, pp. 60-61.

${ }^{14}$ Orlans, Nonprofit Research Institute, pp. 19-21.

${ }^{15}$ Office of Technology Assessment, pp. 53-55.

${ }^{16}$ Orlans, Nonprofit Research Institute, pp. 43-44.

${ }^{17}$ Office of Technology Assessment, p. 24.

${ }^{18}$ Clarence H. Danhof, Government Contracting and Technological Change (Washington, D.C.: The Brookings Institution, 1968), p. 386.

${ }^{19}$ Letter from David E. Lilienthal, Chairman, U.S. Atomic Energy Commission to Leroy A. Wilson, President, American Telephone and Telegraph Company, June 1949 (Sandia National Laboratories' archives).

${ }^{20}$ Quoted in Office of Technology Assessment, p. 29.

${ }^{21}$ Bureau of the Budget Bulletin 60-62, quoted in Orlans, Contracting for Atoms, p. 44.

${ }^{22}$ Danhof, Government Contracting, p. 386.

${ }^{23}$ Orlans, Contracting for Atoms, p. 110.

${ }^{24}$ Address to American Physical Society, April 1961, quoted in Orlans, Contracting for Atoms, p. 108.

${ }^{25}$ Orlans, Nonprofit Research Institute, p. 129. 
${ }^{26}$ Quoted in Office of Technology Assessment, p. 31.

${ }^{27}$ Office of Technology Assessment, p. 29.

${ }^{28}$ Office of Technology Assessment, p. 31.

${ }^{29}$ Office of Technology Assessment, p. 31 .

${ }^{30}$ Orlans, Nonprofit Research Institute, p. 117.

${ }^{31}$ Orlans, Nonprofit Research Institute, p. 113.

${ }^{32}$ Orlans, Nonprofit Research Institute, p. 111.

${ }^{33}$ Office of Technology Assessment, p. 32.

${ }^{34}$ Daniel J. Kevles, Preface, Science-The Endless Frontier, by Vannevar Bush (Washington, D.C.: National Science Foundation, 1990), p. xxii.

${ }^{35}$ Orlans, Nonprofit Research Institute, p. 121.

${ }^{36}$ Sanders, p. 6.

${ }^{37}$ Orlans, Contracting for Atoms, p. 111.

${ }^{38}$ The DoD study was performed by a special Defense Science Board Task Force on Federal Contract Research Center Utilization at the request of Malcolm Currie, then Director of Defense Research and Engineering. Office of Technology Assessment, p. 34.

${ }^{39}$ Office of Technology Assessment, p. 35.

${ }^{40}$ Sanders, pp. 10-11.

${ }^{41}$ Paul G. Kaminski, Statement before the Research and Development Subcommittee, House National Security Committee, March 5, 1996, 104th Congress. Available via the Internet at: http://www.defenselink.mil/speeches/1996/t19960305-kaminski.html

${ }^{42}$ President's Foreign Intelligence Advisory Board, "Science at Its Best; Security at Its Worst: Security Problems at the U.S. Department of Energy," June 15, 1999. Available via the Internet at: http://www.whitehouse.gov/WH/EOP/pfiab/index.html. 


\section{SOURCES CONSULTED}

Argonne National Laboratory. Argonne National Laboratory History. Available via the Internet at http://www.anl.gov/OPA/history.

Baxter, James Phinney, III. Scientists against Time. Boston: Little, Brown, 1946.

Danhof, Clarence H. Government Contracting and Technological Change. Washington, D.C.: The Brookings Institution, 1968.

Davey, Michael E. "DoD's Federally Funded Research and Development Centers FFRDCs," Congressional Research Service Report for Congress, 95-489 SPR. Washington, D.C.: The Library of Congress, Sept. 12, 1995.

Dupree, A. Hunter. Science in the Federal Government: A History of Policies and Activities to 1940. Cambridge, Mass.: Harvard University Press, 1957.

Held, Jennifer and Mary V. Burke. "Master Government List of Federally Funded Research and Development Centers, Fiscal Year 1999.” 1998. Science Resource Studies, National Science Foundation. Available via the Internet at http://www.nsf.gov/sbe/srs/nsf99308/mastlist.htm> (February 1999).

Hewlett, Richard G., and Oscar E. Anderson, Jr. The New World, 1939/1946: Volume I of A History of the United States Atomic Energy Commission. University Park, Penn.: Pennsylvania State University Press, 1962.

Hewlett, Richard G., and Francis Duncan. Atomic Shield, 1947/1952: Volume II of A History of the United States Atomic Energy Commission. University Park, Penn., and London: Pennsylvania State University JPress, 1969.

Kaminski, Paul G. Statement Before the House National Security Committee, Research and Development Subcommittee, March 5, 1996. 104th Congress. Available via the Internet at: http://www.defenselink.mil/speeches/1996/t19960305-kaminski.html.

Kaplan, Fred. The Wizards of Armageddon. New York: Simon and Schuster, 1983.

Kevles, Daniel J. The Physicists: The History of a Scientific Community in Modern America. Cambridge, Mass.: Harvard University Press, 1971, 1995.

Kevles, Daniel J. "Preface." In Science-The Endless Frontier, by Vannevar Bush. Washington, D.C.: National Science Foundation, 1990.

MITRE Corporation. MITRE Corporation Overview. Available via the Internet at: http://www.mitre.org/ about/overview.html.

National Science Foundation. Annotated List of FFRDCs, Fiscal Year 1995. Available via the Internet at: http:/www.nsf.gov/ftp/SRS/s4295/s4295000.txt.

National Science Foundation. Master Government List of Federally Funded Research and Development Centers, Fiscal Year 1996. Available via the Internet at: http://www.nsf.gov/ftp/SRS/s4596/s4596000.txt.

Office of Technology Assessment. A History of the Department of Defense Federally Funded Research and Development Centers. Springfield, Va.: National Technical Information Service, 1995. 
Orlans, Harold. Contracting for Atoms. Westport, Conn.: Greenwood Press, 1967.

Orlans, Harold. The Nonprofit Research Institute: Its Origin, Operation, Problems, and Prospects. New York: McGraw-Hill, 1972.

Sanders, Douglas L. "Capturing Private Research and Development for Public Ends: The Government's Use of FFRDCS.” National Contract Management Journal 26:1, 1995: pp. 45-59. Available from Dialog, B-NCMJ-12-5.

Tybout, Richard A. Government Contracting in Atomic Energy. Ann Arbor: The University of Michigan Press, 1956. 


\section{DISTRIBUTION:}

1 Department of History

1104 Mesa Vista Hall

University of New Mexico

Albuquerque, NM 87131-1181

$\begin{array}{lrl}1 & \text { MS } 0127 & \text { D. P. Garber, } 12111 \\ 1 & 0129 & \text { N. S. Hey, 12600 } \\ 10 & 0131 & \text { B. C. Dale, 12112 } \\ 1 & 0141 & \text { M. R. Kestenbaum, 11000 } \\ 1 & 0165 & \text { W. R. Geer, 12640 } \\ 1 & 0165 & \text { N. E. Singer, 12640 } \\ 1 & 0180 & \text { G. B. Zura, 10001 } \\ 1 & 0612 & \text { R. A. Ullich, 9612 } \\ 1 & 0839 & \text { T. D. Moy, 16000 } \\ 1 & 1490 & \text { J. K. Walther, 12660 } \\ 1 & 1490 & \text { S. Bono, 12660 } \\ 2 & 1490 & \text { A. M. Lucero, 12660 } \\ 1 & 1490 & \text { J. A. Wadell, 12660 } \\ 1 & 9018 & \text { Central Technical Files, 8945-1 } \\ 2 & 0899 & \text { Technical Library, 9616 } \\ 1 & 0612 & \text { Review \& Approval Desk, 9612 } \\ & & \text { For DOE/OSTI }\end{array}$

